\title{
The Adoption of Computerized Accounting System in Small Medium Enterprises in Melaka, Malaysia
}

\author{
Mohd Fazli Mohd Sam ${ }^{1,2}$, Yasuo Hoshino ${ }^{1} \&$ Md. Nor Hayati Tahir ${ }^{2}$ \\ ${ }^{1}$ Graduate School of Business Administration, Aichi University, Nagoya, Japan \\ ${ }^{2}$ Faculty of Technology Management and Technopreneurship, University of Technical Malaysia Melaka, Melaka, \\ Malaysia \\ Correspondence: Mohd Fazli Mohd Sam, Graduate School of Business Administration, Aichi University, 10-31 \\ Tsutsui 2-Chome, Higashi-ku, Nagoya, Aichi-ken 461-8641, Japan. Tel: 81-804-545-6061. E-mail: \\ mohd.fazli@utem.edu.my
}

Received: June 24, 2012 Accepted: July 19, 2012 Online Published: September 16, 2012

doi:10.5539/ijbm.v7n18p12 URL: http://dx.doi.org/10.5539/ijbm.v7n18p12

\begin{abstract}
The increasing competition and the highly demands of globalization, Malaysia government attempt for Small Medium Enterprise, SME for the development of innovative, competitive with high technology. Computerized accounting system (CAS) adoption may be decisive factor for an organization to be success and also to survive.

This research project which aimed to investigate SME practice of CAS and to identify the factor affecting the adoption among SMEs in Melaka. A survey was carried out through a set of questionnaires to examine the CEO Innovativeness Factors Scale, Perceive Usefulness Factors Scale, Perceive Ease of Use Factors Scale and Business Competitiveness. The sample selected comprised of CEOs of SMEs in three districts in Melaka, namely Melaka Tengah, Alor Gajah and Jasin. The data gathered were coded and analyzed using descriptive statistics, linear regression analysis, Pearson Correlation analysis and Analysis of Variance (ANOVA).

This study reveals that CAS adoption rate in SMEs in Melaka is high. Results from the analysis also shown the significant of independent variables and proved the relationships have been substantiated to the dependent variable which contribute to the usage of CAS adoption between SMEs in Melaka. The findings indicate that CEO innovativeness; perceive ease of use and business competitiveness negatively correlated to the adoption of CAS. Results reveals that only perceive usefulness are significantly positive correlated to CAS adoption. Therefore it can be deduced that adoption of CAS among SMEs in Melaka is caused by its usefulness.

The findings reveal that types of business and business location influence the adoption of CAS. However, size (paid up capital, sales turnover and number of employee) do not influence the adopter. Results also indicate that CEO literacy on ICT, accounting and CAS has influence the responded CEO to adopt CAS in their business. However, the advantages by using the accounting systems software were not fully utilized by CAS adopters.
\end{abstract}

Keywords: computerized accounting system, small and medium enterprise, adoption, innovativeness, business competitiveness

\section{Introduction}

In a dynamic world, the availability and adoption of Information and Communication Technologies (ICTs) across the globe has altered the norm of the game and expectations of the new mode of economics activities. The norm of inter and transnational trading changed dramatically to admit the increasing number of financial transactions and trade-related activities that take place via the Internet and technologically assisted tools.

The traditional view of small business record keeping suggest that it is a paper based and hand of to the accountant firm to prepare the annual tax return. Porter \& Millar (1985) mentioned in this competitive advantage, over the years, information technology had played a major role, changing the nature of business who knows its effects. With the introduction of new technology and more user friendly software, computerized accounting system (CAS) appears to reduce the problems in book record keeping practice. Furthermore, with the new and rapid financial information, new updates and changes will be available for others in making decisions.

Profitability through price competitiveness and also quality of their services and products were the target in 
Small and Medium Enterprises (SMEs) as a profit seeking organizations. To survive and grow, SMEs need more non-financial information such as customer behavior, market trends and price changes, besides the fundamental of financial reports, Chenhall \& Morris (1986). Changes in information are constant with the changing environment. With lower labor costs that offered by China and Vietnam gives a global competitive in Malaysia SMEs environment. Therefore, without the use of technology such as computerized accounting system, it will be more difficult for the SMEs to make a good decision. In the Northern Region of Malaysia, CAS usage in SMEs are at the early stage as most of the firms adopt this technology within six years or less Noor et. al. (2003). Powell and Xiao (1996) and Duchinsky and Dunn (1998) mentioned that UK companies adopted this system and limited to fundamental accounting components. Study conducted by Josept and Janggu (2003) in Kuching Sarawak found that the rate of adoption of computerized accounting system is minimal 52 percent.

Shaping the future of the local economic landscape had changed dramatically and it is important that efforts for a more equitable and sustainable progress towards may not stop ICT adoption by SMEs in the region. SME's is in transition, moving rapidly from "production driven" to "knowledge and information based". In Malaysia, SMEs play an important role. By contributing to expand output, provide value-added in the manufacturing sector, create jobs and help expand the country's export-based activities (UNDP, 2007). Furthermore, in 2003 Malaysia SMEs represent $99 \%$ of business establishments, employs more than three million workers and create a total added value of RM 54 billion, Census (2005). The increasing competition and the highly demands of globalization, Malaysia government attempt for Small Medium Enterprise, SME for the development of innovative, competitive with high technology according to the 9th Malaysia Plan from year 2006 to 2010. By achieving industrialized nation status by 2020 , Malaysia SMEs is seen as a potential factor.

This research aims to determine the factors that influence the use of CAS among SMEs in Melaka. The main objective of this study is to observe related issues on the application of CAS with the CEOs of SME in Melaka. The objectives are whether CEO innovativeness influence the adoption of CAS, to determine the perceiveness of use influence the adoption of CAS, perceive usefulness in the adoption of CAS and to determine whether business competition influence the adoption of CAS in SMEs in Melaka.

Thus, the results of this research will give an important indicator of the willingness of SMEs in Malacca towards future challenges by adopting a CAS, could speed-up the preparation of financial reports on time. A complete CAS should allow the management to make an important predictions to compete in the global economy and also an important indicator for achieving the status of "Melaka Maju 2010" where small and medium industries play an important role to achieve this objective.

This study examined factors of the CAS adoption including the contexts of CEO characteristic, business competition, perceive ease of use and perceive usefulness. Data was gathered from 180 SMEs' Chief Executive Officers (CEO) in Melaka from participating organizations in the three districts of Melaka that are Melaka Tengah, Alor Gajah and Jasin. Organizational structure of SMEs is less complex and CEO used to be the owner and main decision-maker of the business. Hence, CEOs' characteristic and perceive towards CAS can represent the organizational intention to adopt CAS.

\section{CAS Adoption Factors}

Linda (2004) noted that there are two functions in record keeping, namely: to provide entrepreneurs business operation and a complete and easy set to record the business activity by providing income tax information which is widely available and verifiable. A good accounting system should give an accurate and comprehensive results of operations, which allow quick comparison between current and previous years data, offers the financial statements to be used by prospective creditors, bankers and management, facilitate filing reports and tax returns to government regulatory agencies and tax-collecting, and disclosing record keeping error, waste, theft, and employee misconduct, Longenecker, et al. (2006) However, this study also showed that many entrepreneurs simply do not keep sufficient records and/or that they do not benefit the use of their financial statements.

A more simplistic view is presented by Klien (2002) stressed that a business either small or big business must have equivalent accounts namely, the income, capital, expenses and liabilities Small business need to track its assets, liabilities, income and the expenses. Various software package introduce such as interface, wizards file, icon and pre built templates for multipurpose. It can be memorizes by saving the data and the forms that been used regularly. By using this feature, record keeping will be consistent and also save time, Davis and Dunn (2005).

This study consolidated Thong (1999) research model and Davis (1989) Technological Acceptance Model as framework that is useful in studying variables that affect the adoption of CAS. According to Thong (1999) owner-managers particularly features important characteristics towards education, knowledge level in IT, 
experience in IT training, innovativeness IT adoption and computer self- efficiency. Capability using a computer was defined by Compeau and Higgins (1995) in computer self- efficiency. CEO is usually the owner-manager in a small and medium business, Thong (1999). Determining the innovation attitude in small and medium business are the most critical for the CEO as a decision maker, Rizzoni (1991). Meanwhile, process in the IT decisions making were made by large business teams. This is different to the small and medium business, where in IT decision were done by the owner-managers, Thong (1999). According to Frissen (1999) in small and medium business, decision making is done by one-person, either the entrepreneur, director or the self-employed owner. As a consequence the owner had the maximum autonomy in this small and medium business.

Kirton (1976) mentioned that everyone able to things with their own ability and differently within its own range. The range is known as innovators and adaptors. In adapter, CEO will find solutions which he/she had understood and known meanwhile, in the innovator, vice versa. If the CEO or others members in the business has the spirit to innovate by adopting information system or extent the adoption in information system, Thong (1999). Rogers (1983) in his innovation theory mentioned that attitude of an individual firm towards innovation, which lead to the decision to accept or reject and, if the decision is to adopt is to implement the innovation in their business activity.

There is a strong link between qualifications of their leaders and technology-driven firm. According to Lal, (2006) finding educational attainment of company directors who are related to the use of ICT and further stressed that one possible clarification for the low level of IT usage in Malaysia is that most SME owners are anxious in IT and also because of their unfamiliarity of the technology. IT implementation in small business is more likely to be conduct by CEO (business owner), who has been conducting computer training and have their own computer efficiency IT (Delone 1988, Raymond 1988). Ettlie (1990), CEOs with greater knowledge in technological innovation is significantly more likely to implement an aggressive technology adoption policy. Lacking in basic knowledge and awareness in information systems were found in the CEO small and medium businesses, Gable \& Raman (1992). Unfamiliarity of IT was the main cause why most of them are less concern and do not know the benefits using information system. If the owner (CEO) knows the importance of CAS, technology adoption is ready for them.

This seems to imply that, if CEOs have knowledge about the benefits of CAS, they would be willing to adopt such technology. Furthermore, further stressed that they have to be provided further insight that required skills in IT besides the basic skill needed by the small business owner-manager, Feeney \& Wilcox (1998). Instead, the owner-manager can prevent any worthwhile IT performance through group or hostility to the IT (Thatcher and Perrewe, 2002). Therefore, owner-manager has IT adoption efficiency in small and medium business.

Outsourcing the accounting work to the public accounting firm is preferred by the small and medium businesses. By outsourcing, the awareness of the importance and the benefit in using IT is low, Lees (1987); Delone (1988) and Niedleman (1979). These knowledge deficiencies will create a barrier to CAS adoption. By this study, CEO will be exposed to the importance and the benefits in using IT. According to Longenecker, et al. (2006), small and medium business owners-managers are not expert in accounting but they should know the process including the financial statements and identify the best methods can be apply to its business.

The characteristics of the organization are other variables that influences the decision whether to adopt IT. Organizational characteristics such as business size, employee's level of IT knowledge, industry sector, business location, and information-intensity has been analyzed in previous research studies by Wenzler, (1996); Attewell, (1992); and Delone, (1988).

Generally, the larger the number of employees, the greater the sales turnover, the more information-intensive the industry and the more likely a small business will adopt IT innovation. Moreover, small businesses tend to suffer resource poverty (Thong, 1999) in terms of financial capacity, available time and IT skilled staff to facilitate innovation adoption. Consequently, resource poverty raises the barrier to innovation adoption in small business (Attewell, 1992).

Past literature in technology innovation, more resources and infrastructure in large businesses to facilitate the adoption of innovation (Dewar and Dutton, 1983; Moch and Morse, 1977). Barriers that small and medium businesses had to face such as limited financial resources, lack of expertise in-house information system to adopt information system (Ein-Dor and Segev, 1978). Alpar \& Reeves, (1990) mentioned that, knowledge of information systems, even among small businesses able to hire people with specific skills.

Environmental characteristics related to organizations operating variables such as external agents and competition. Competition may lead to the use of innovative technology. Wholesalers, trade associations, franchisors and voluntary groups were influenced from high IT adoption by small businesses, Treadgold (1990). 
Wenzler (1996) identify that the reason behind implementing IT in their business are their customers rather than the competitor.

Competition is generally believed to increase the probability of innovation adoption (Thong, 1999). Competition led to the uncertainty of the environment and enhances both the rate and the need of adoption of innovations. Porter and Millar (1985) suggests that, there are three ways businesses can adopt IT. By changing the competition rules, as well as changing the industry structure. IT can create competitive advantage by reducing costs or increase differentiation. Finally, IT seed new businesses by creating a demand from new products, often in the existing business operations.

Adopt an innovation are also affected by peer pressure associated to the "diffusion effect," which is, the degree of influence on individual outstanding increased by 1 or an organization to approve or reject the innovation, resulting from activation of the peer network in social system (Rogers, 1983). Firms may end up adopting because of perceived competitive necessity (or even sheer imitation) rather than as a result of a cost/benefit assessment (O'Callaghan, 2005).

\subsection{Relationship between Adoption of CAS and CEOs Characteristic}

From the preceding literature review, this section develops a research framework that best describe the relationship for all the independent variables and dependent variables. The dependent variable is the use of CAS. Definition by Davis and Olson (1985), to support management, operations and decision making in business, adoption in information system by using computer software and hardware applications. In this research, by using at least one module of accounting application was defined as computerized. Powell \& Xiao (1996), the number of accounting modules in use and the level of integration among the modules will be used to measure the size of the use of CAS, CAS sophistication adopted,.

There will several independent variables such as, characteristic of organization decision maker (CEO innovativeness), business environment (competition) and perception towards CAS (usefulness and ease of use). CEO innovativeness was chosen among all because as mentioned above according to Rogers' innovation theory, an individual firm attitude towards innovation, which led to the decision to accept or reject. Therefore, the potential adopter perception towards the use of IT is the main determinant of CAS (Rogers, 1983).

\section{Methodology}

The goal of this descriptive study is to describe the relative importance of the characteristic of CEO, organization characteristic and business environment to the adoption of CAS among SMEs in manufacturing sector in Melaka Further, hypotheses developed were tested to enhance the understanding of the relationship between the variables. Data collection was done in two phases: questionnaire and pilot study. The factor analysis and Cronbach's alpha computed to establish the validity and reliability of data. A structured questionnaire will be mailed to the CEO (owners-managers). CEO is the person who decides to adopt CAS in their business, Thong (1999). In deciding sample companies, this study utilized the list of SMEs located in Melaka as listed in Direktori Usahawan Bumiputra Melaka 2006. To undertake this study, there are two types of data that consists of primary data and secondary data. All data will be discussed using descriptive statistic such as frequencies. Statistical Package for Social Sciences (SPSS) 16.0 will be used to formulate the data collected from the study. Multiple linear regression techniques will be used to test the hypotheses.

\section{Findings}

\subsection{Respondent Profile}

In terms of geographical location, 54 (40.30\%) companies are located in Melaka Tengah, 32 (23.9\%) companies in Alor Gajah and 48 (35.8\%) companies being located in Jasin (Appendix A). SMEs in Malaysia fall into two broad categories, manufacturing and services. Thus, responded CEOs were classified according to the types of industry they operated. Manufacturing represented by 85 (63.4\%) companies sample and 49 (36.6\%) companies from services sector. This suggests that majority of the sample from manufacturing sector. There are $84(62.7 \%)$ companies have been operating for three to six years. Only $8 \%$ of the companies studied operated more than 9 years. Others have been operating less than 3 years. Majority of the respondents, 85 (63.4\%) companies paid up capital is below RM500,000 and 34 (25.4\%) companies is between RM 500,000 to RM 1 million. This suggest that majority of the responded companies $(63.4 \%)$ have a small capital and small capital company unsufficient from financial ability, skilled It staff and time available to adopt, Thong (1999).

To confirm whether the responded companies were under small medium enterprise category, number of employee is one of the important factors. The finding shows $100 \%$ of the responded companies having employee less than 150 that suggest respondents are small medium enterprises. Beside number of employee, company sales 
turnover was also the important determinant to categorized SME companies. All responded company having sales turnover below RM10 million per year. The result reveals that most of the companies' yearly turnover is less than RM250,000 (70.1\%) and 29.9\% is between RM250,000 and RM10 million. This confirmed that all responded companies studied falls under small enterprises.

\subsection{Preparation of Company Account}

The result illustrates that most of the companies (65.7\%) prepare company account internally. However there are still $34.3 \%$ of the companies outsource the preparation of company account to accounting firm. Even only $65.7 \%$ of the companies prepared account internally, $79.9 \%$ of the companies using the CAS. This suggests that 19 companies (14.2\%) that outsource the preparation of account is using CAS since it is defined as the use of computerized if it uses at least one module such as ledger.

The finding also revealed that majority of the companies (81) is using the CAS purchased from vendor (Integrated accounting system) which ease of use rather flexibility and customized functionality for example UBS accounting system and MPOB. Only 26 companies using internally developed system (modular accounting system) that is customized according to customer needs.

\subsection{Characteristic of CEO}

There are four criteria that are related to characteristic of CEO namely the ownership, accounting literacy, ICT literacy and CAS literacy. Finding shows that $90.3 \%$ CEO having majority shares in the company and owner-decision maker of the company. Therefore, their characteristics are important in determining the attitude of small and medium business innovation (Rizzoni, 1991). Majority of the CEO have at least basic knowledge/literacy in ICT. Only small number of CEO that is $15(11.2 \%)$ does not literate in ICT. The result reveals that $100 \%$ of the respondents literate in accounting with $44 \%$ least basic accounting literacy where $11.9 \%$ of the respondent expert in accounting. Whilst, $46.3 \%$ CEOs do not literate in CAS, $33.6 \%$ CEOs have a basic literacy in CAS and only $2.2 \%$ CEOs expert in CAS.

\section{4 Hypothesis Testing Result}

Hypothesis 1: CEO innovativeness influences the adoption of CAS in SMEs in Melaka.

There is a significant relationship between CEO innovativeness and the adoption of CAS as shown in Table 1. So, we have to reject the Ho hypothesis and accept the H1 hypothesis. The result indicated that there was a medium, negative correlation between CEO innovativeness and adoption of CAS, $r=-.351, p<.001$. This explains that CEO innovativeness factors play a role in influencing CAS adoption among SMEs in Melaka. The Pearson correlation coefficient result indicated that there was a medium, negative correlation between CEO innovativeness and adoption of CAS. On the other hand CEO literacy on ICT, accounting and CAS do have positive relation on the adoption of CAS. This support by Cross tabulation outcome reveals that most of the CAS adopter have at least a basic knowledge and skill on ICT, accounting and CAS.

Table 1. Relationship between CEO innovativeness and usage of CAS

\begin{tabular}{llcc}
\hline & & Company usage CAS & CEO innovativeness \\
\hline Company usage CAS & Pearson Correlation & 1 & $-.351^{* *}$ \\
& Sig. (2-tailed) & & .000 \\
& $\mathrm{~N}$ & 134 & 134 \\
CEO innovativeness & Pearson Correlation & $-.351^{* *}$ & 1 \\
& Sig. (2-tailed) & .000 & 134 \\
& $\mathrm{~N}$ & 134 & \\
\hline
\end{tabular}

**. Correlation is significant at the 0.01 level (2-tailed).

Hypothesis 2: Perceiveness of use influence the adoption of CAS in SMEs in Melaka.

The figures in Table 2 were analyzed using Pearson product-moment correlation coefficient. This result revealed that there was a strong, positive correlation perceive of influence and usage of CAS, $(\mathrm{r}=.539, \mathrm{p}<.001)$. This suggests that perceive usefulness have positive effects on influencing the adoption of CAS among SMEs in 
Melaka. Thus, the Ho hypothesis rejected and accepts the $\mathrm{H} 2$ hypothesis.

Table 2. Relationship between perceive of influence and usage of CAS

\begin{tabular}{clcc}
\hline & & Company usage CAS & Perceive usefulness \\
\hline Company usage CAS & Pearson Correlation & 1 & $.539^{* *}$ \\
& Sig. (2-tailed) & & .000 \\
& $\mathrm{~N}$ & 134 & 134 \\
\multirow{2}{*}{ Perceive usefulness } & Pearson Correlation & $.539^{* *}$ & 1 \\
& Sig. (2-tailed) & .000 & 134 \\
& $\mathrm{~N}$ & 134 &
\end{tabular}

**. Correlation is significant at the 0.01 level (2-tailed)

Hypothesis 3: Perceive usefulness in the adoption of CAS in SMEs in Melaka.

Based on the correlation between perceive ease of use and usage or adoption of CAS as shown in Table 3, it is found that there was a strong, negative correlation, $(\mathrm{r}=-.541, \mathrm{p}<.001)$. The fact is that majority of the company that adopt CAS, the CEO having very little knowledge and skill on CAS, $60 \%$ of the respondent is under nil and basic scale. The result proved that perceive ease of use is one of the important variables to determine the factor influencing the adoption of CAS and we reject the Ho hypothesis and accept the H3 hypothesis.

Hypothesis 4: Business competitions influence the adoption of CAS in SMEs in Melaka.

Relationship between business competition and usage of CAS reveals that there is a small, negative correlation between business competition and adoption of CAS, $(r=-.338, p<.001)$ as shown in Table 3 . This suggests that business competition factors also play some role as influence factors of CAS adoption. Based on findings the Ho hypothesis rejected and the $\mathrm{H} 4$ hypothesis accepted

Table 3. Business competitions influence the adoption of CAS in SMEs in Melaka

\begin{tabular}{llcc}
\hline & & Company usage CAS & Business competition \\
\hline Company usage CAS & Pearson Correlation & 1 & $-.338^{* *}$ \\
& Sig. (2-tailed) & & .000 \\
& $\mathrm{~N}$ & 134 & 134 \\
Business competition & Pearson Correlation & $-.338^{* *}$ & 1 \\
& Sig. (2-tailed) & .000 & 134 \\
& $\mathrm{~N}$ & 134 & \\
\hline
\end{tabular}

**. Correlation is significant at the 0.01 level (2-tailed)

Hypothesis 5: The four independent variables influence the adoption of CAS in SME in Melaka.

Testing the influence of all four independent variable to the adoption of CAS, it is found that this model account for $61.5 \%$ of variance in the factor influence the adoption of CAS among SMEs in Melaka as shown in Table 4.

Table 4. Multiple linear regression - output 1

\begin{tabular}{ccccc}
\hline \multicolumn{5}{c}{ Model Summary } \\
\hline Model & $\mathrm{R}$ & R Square & Adjusted R Square & Std. Error of the Estimate \\
\hline 1 & $.792^{\mathrm{a}}$ & .627 & .615 & .24973
\end{tabular}

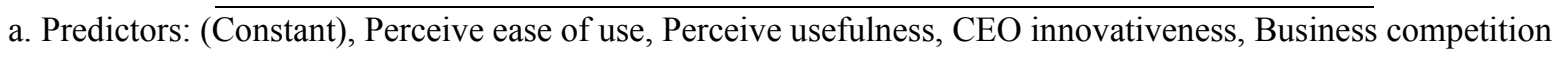


Table 5. Multiple linear regression - output 2

\begin{tabular}{llccccc}
\hline \multicolumn{6}{c}{ ANOVA $^{\mathrm{b}}$} \\
\hline \multicolumn{1}{l}{ Model } & Sum of Squares & Df & Mean Square & F & Sig. \\
\hline 1 & Regression & 13.515 & 4 & 3.379 & 54.177 & $.000^{\mathrm{a}}$ \\
& Residual & 8.045 & 129 & .062 & & \\
& Total & 21.560 & 133 & & & \\
\hline
\end{tabular}

a. Predictors: (Constant), PEOU, PU, CEO innovativeness, Business competition

b. Dependent Variable: Company usage CAS

In term of overall significant of this model, Table 5 shows that significant model emerged $(F 4,129=54.177, \mathrm{p}<$ $0.001)$.

Table 6. Multiple linear regression - output 3

\begin{tabular}{|c|c|c|c|c|c|c|}
\hline \multicolumn{7}{|c|}{ Coefficients $^{\mathrm{a}}$} \\
\hline & \multirow[b]{2}{*}{ Model } & \multicolumn{2}{|c|}{ Unstandardized Coefficients } & \multirow{2}{*}{$\frac{\text { Standardized Coefficients }}{\text { Beta }}$} & \multirow[b]{2}{*}{$\mathrm{t}$} & \multirow[b]{2}{*}{ Sig. } \\
\hline & & B & Std. Error & & & \\
\hline \multirow[t]{5}{*}{1} & (Constant) & 1.662 & .250 & & 6.645 & .000 \\
\hline & Perceive usefulness (PU) & .035 & .004 & .483 & 8.426 & .000 \\
\hline & Business competition (BC) & -.009 & .004 & -.130 & -2.241 & .027 \\
\hline & CEO innovativeness (CEO) & -.021 & .003 & -.337 & -6.040 & .000 \\
\hline & Perceive ease of use (PEOU) & -.032 & .005 & -.377 & -6.638 & .000 \\
\hline
\end{tabular}

a. Dependent Variable: Company usage CAS

The perceive usefulness, business competition, CEO innovativeness and perceive ease of use are significant variable for this model $(\mathrm{p}<0.05)$. Based on regression analysis outcome, the Ho hypothesis rejected and the H5 hypothesis accepted. In this study, the relationship between the independent variables and dependent variable from regression analysis is:

$$
\begin{aligned}
\text { CAS Adoption }= & 0.483 P U-0.130 B C-0.337 C E O-0.337 P E O U \\
& (8.426)
\end{aligned}
$$

where $t$ value is in parentheses.

This indicates that CAS adoption will increase by 0.483 when PU goes up by one (holding other variables constant), decrease by 0.130 when business competition goes up by one (holding other variables constant), decrease by 0.337 when CEO innovativeness goes up by one (holding other variables constant) and decrease by 0.337 when PEOU goes up by one (holding other variables constant). In conclusion the findings that have been gathered revealed the variables have positive and negative influence the adoption of CAS. The finding also reveals that the model used is significant and the four variables were significant for this model.

\section{Conclusions}

This study revealed that from the 180 questionnaires, only 134 complete sets for analysis. Response rate was presented by $74 \%$. An analysis indicates that $85(63 \%)$ of the respondents from manufacturing sector. Majority of the respondent having employee less than 55 (84\%) with total annual revenues less than RM250,000 for 70\% of the respondent. The frequency analysis also revealed that almost $90 \%$ of the responded CEO is the majority shareholder of the company.

As for the adoption of CAS, the findings reveal that almost $80 \%$ of the SMEs have adopted CAS at various stages of implementation. The result of this study was consistent with the empirical study by Thong (1999) that stated with the use of several accounting software, barriers to IT innovation adoption are reduced. IT adoption in small business had increase. This has led to an increase in the adoption of IT by small business. 
Based on the first objective, the independent variable is the CEO innovativeness. Rogers (2003) defined innovativeness as "the degree to which an individual is relatively earlier in adopting new ideas than other members of a system" (p. 267). Pearson correlation coefficient result reveals that there was medium, negative correlation between CEO innovativeness and CAS adoption among SMEs in Melaka. This finding highlight that CEO innovativeness has a negative impact on CAS adoption. Thus, further analysis using cross tabulation was carried out to study whether others CEO characteristic will influence the adoption of CAS. ICT literacy in this study defined as a judgment of the ability to use a computer. According to the previous study, a person will be easy to adopt a computerized accounting system if they know to use a computer. By using these factors, the user group of CAS had a higher proportion of CEO that literate with at least basic skill and knowledge on ICT (80\%) compared to non-users consist of responded CEO that have no skill and knowledge on ICT (11\%) and basic skill (9\%). Cross tabulation analysis also reveals that $80 \%$ of the responded CEO that adopts CAS has at least basic knowledge of accounting and $33 \%$ of CAS adopter does not literate on CAS, while $42 \%$ of those identified as having basic CAS literacy. There are no strong link between CAS literacy and CAS adoption. A conceivable explanation is the importance of CAS mitigates the necessity for CEO to literate in CAS as long as the company concerns have the skill staff to operate the system. Evidently, the CEO innovativeness is not a positive influence to the CEO of SMEs in Melaka to adopt a CAS.

Perceived usefulness is the second independent variable in this study. As mentioned earlier, the availability of user-friendly accounting software has improved the benefits of adopting CAS. Burges (1997), increase business efficiency and facilitate the timely information are the main benefits in implementing CAS. Therefore, findings highlight a strong positive perception of the usefulness of CAS among respondent. The majority of CEO considered that the CAS can improve job performance $(\mathrm{M}=3.91, \mathrm{SD}=1.12)$, CAS support decision making $(\mathrm{M}=3.78, \mathrm{SD}=.396)$, CAS give owner more control over company account $(\mathrm{M}=3.75, \mathrm{SD}=1.03)$. Moreover, there is one question on their overall perception whether the CAS is useful for the company and the mean (3.25) indicated that responded CEO perceive that CAS is useful on their business. Further analysis is to analyze the relationship between perceive usefulness and CAS adoption. Evidently, there is a strong positive influence of perceive usefulness and CAS adoption $(\mathrm{r}=.539, \mathrm{p}<0.001)$. The result of this study confirmed prior studies where CEOs' perception of usefulness was a significant predictor of CAS adoption (Tan \& Teo, 1998). Thus, this support the objective where perceive usefulness can influence CAS adoption on SMEs Melaka.

The third independent variable is perceived ease of use. The conclusion can be made where $33 \%$ of the CAS adopters do not literate in CAS and $42 \%$ have a basic skill and knowledge in CAS. Overall, $75 \%$ of the CAS adopters were not familiar with CAS. This outcome supported by the fact that the lowest mean is CEO perception that learning to operate CAS is easy $(\mathrm{M}=2.96)$. However, the mean for interaction with CAS clear and understandable $(\mathrm{M}=3.82)$ and easy to produce report using CAS $(\mathrm{M}=3.49)$ among the highest means. This outcome can be cause by the situation whereby the CEOs only access the CAS to get financial report and not involved directly in preparing the account using CAS. In this study, the main focus was on how CEOs perceptions that CAS is easy to use can influence the adoption of CAS. The finding showed that there is strong negative relationship between CEO perceives ease of use and the adoption of CAS $(r=-.531, p<.001)$. This evidence reveal that the CEO perceive ease of use does not have positive influence on CAS adoption and the finding may suggest that the adoption of CAS is strongly influenced by the perceive usefulness.

From the literature above, these external factors such as suppliers, competitors, customers and accounting firm can influence the adoption of CAS. This research only focus on how responded CEO perceived that their business is competitive and to test whether this factor influence the adoption of CAS. The study reveals that businesses competitiveness has a significant negative relation with the adoption of CAS $(r=-.338, p<.001)$. Further cross tabulation analysis was carried out to determine what other factors related to the business that might effect the adoption of CAS. First result indicates that 77 companies out of 107 companies adopt CAS $(70 \%)$ is from manufacturing company. This suggests that the respondent believed that their organizations were in an industry of high information intensity, that means that the organizations needed up to date, reliable and accurate information anytime. The finding of this study was consistent with prior study (Thong, 1999) that higher information intensity would lead an organization to perceive CAS as a competitive tool.

Second, the highest portion of the CAS adopter is from Melaka Tengah District (50 out of 54), followed by Jasin District (35 out of 40) then Alor Gajah (22 out of 32). The organization located in Melaka Tengah was more likely than expected to adopt CAS earlier than other district. This is because of Melaka Tengah District known to be the central resources in terms of finance, technology information and human resource compared to other districts in Melaka.

Finally, from the result above shows that neither size of a business or age indicates the clear pattern on CAS 
adoption. This evidence suggests that there is no correlation between the number of years in business, paid up capital, sales turnover per year and number of employee with the adoption of CAS. The findings had matched with the earlier studies that the company size was not correlated, with the use of accounting system (Hunton and Flowers, 1997). Previous studies suggested that the difference may be the capital constraints and lower risks due to the dramatic reduction in IT costs where all firms will get the benefit from the latest IT development. Thus, from the finding it can be concluded that business competitiveness have negative influence on CAS adoption. In fact, type of business and business location show the positive relationship with CAS adoption.

Majority of the firms adopted the most popular method of implementation is available through the purchase of finished packages. Because of the easy-to-use software and low-cost which satisfy the needs for owners-managers. Only 19\% of respondents developed their own packages because the lacking of IT expertise in their business organization to develop the accounting system. The findings is matched with previous study by by Gray (1991) and Shahrum et al., (1996) where the most respondents used the ready-made accounting software. Based on this finding, while the adoption rate of CAs is high, it can be reduced, the extent of CAS adopted by SMEs in Melaka is still behind from the industrialized nations (Powell \& Xiao, 1996; Henry, 1997; Duchinsky and Dunn, 1998 and Everdingen et al., 2000).

Evidence indicates that SMEs do not fully utilize the technology offered by the accounting system. The study may educate SMEs in Melaka to benefit from the extensive use of CAS since CAS offers greater benefits than those offered by the basic accounting modules. If these systems can be included in Malaysian SMEs, CAS will provide great assistance in making better decisions because they provide a report that contains information about future scenarios.

This paper investigated the variables relationship with the CAS adoption. The finding indicates that CEO innovativeness; perceive ease of use and business competitiveness negatively correlated to the adoption of CAS. Result indicates that only perceive usefulness are significantly positive correlated to CAS adoption. Therefore it can be deduced that adoption of CAS among SMEs in Melaka because of its usefulness.

Finally, the research has also identified other factors that influence the CAS adopter. The finding reveals that types of business and business location influence the adoption of CAS. However, size (paid up capital, sales turnover and number of employee) do not influence the adopter. Results also indicate that CEO literacy on ICT, accounting and CAS has influence the responded CEO to adopt CAS in their business. Evidently, the responded company does not have enough experience staff to operate CAS. Thus, the finding support the conclusion made by Thong (2001), that there are three types of resource barriers of SMEs in IT adoption including expertise constraint.

To conclude, the regression model analysis showed that the relationship between CAS adoption (dependent variable) and CEO innovativeness; perceive usefulness, perceive ease of use and business competitiveness (independent variables) had explain $61.5 \%$ of the variance in the factor influence the adoption of CAS among SMEs in Melaka.

\section{Recommendations}

It is proposed that the government should provide appropriate incentives to encourage the use of CAS. Usually fully integrated accounting software is very expensive to obtain and tax relief from this acquisition by the government will reduce the financial burden of SMEs. In the information age and globalization, time relevant and the actual information in hand, a correct result needs to achieve by SMEs in Malaysia. Data security is another important issue of the computerization of accounting systems. Although our evidence shows that the majority of respondents have implemented various security measures, there is a need to strengthen security measures, especially among the minority.

With respect to trying to introduce non-users to a CAS, it may be useful to consider business operators those who are uninformed about the benefits of using a CAS. This lack of knowledge may be a further result of the deficiency in IT skills as reported by almost half of the non-user respondents Government should set up training organizations offers a CAS specific skills development program targeted to those involved in small businesses, to avoid reluctance among retailers about the effectiveness in computer self-efficacy.

Further studies are needed as we move towards the better adoption of fully integrated accounting system in SMEs in Melaka to obtain more information and gather different opinions of CEOs' by conducting a thorough survey, using a qualitative research to view the results from different perspective. The accessible population for this study was all CEOs for selected companies for each district in Melaka. However, expanding the population through other category, for example employee, might be useful. This is because researchers are able to identify 
the influences of the identified independents variable on CAS adoption from employee point of view. This, to a certain extent, will ascertain whether the employee perception influence the adoption of CAS. The findings of this research had significant effects for the government agencies that are responsible for promoting IT adoption within SMEs.

In conclusion, recognition of these recommendations is important because by adopting the computerized accounting systems (CAS), will determine the success of a business organization. As a major role to achieve Malaysia's aspiration to become a fully developed nation by year 2020, SMEs need to consider about implementing this technology.

\section{References}

Acs, Z. J. (1992). Small business economics: a global perspective. Challenge, 35-34.

Alpar, P., \& Reeves, S. (1990). Predictors of MS/OR application in small businesses. Interfaces, 20(2), 2-11. http://dx.doi.org/10.1287/inte.20.2.2

Attewell, P., Technology Diffusion and Organizational Learning: The Case of Business

Census. (2005). Census of Establishments and Enterprises. Department of Statistics, Kuala Lumpur, Malaysia.

Chen, J. C., \& William, R. C. (1993). The Impact of Microcomputer Systems on Small Business. Journal of Small Business Management, 31(3), 97-102.

Chenhall, R. H., and D. Morris. (1986). The Impact of Structure, Environment, and Interdependence on the Perceived Usefulness of Management Accounting Systems. The Accounting Review. LXI(1), 16-35.

Clyman, J., McLaughlin, M., Steinhart, M., \& Gambhir S. (2004). Manage Your Money \& Employees. PC Magazine, 23(21).

Collins, J. C. (1999). How to Select the Right Accounting Software. Journal of Accountancy, October, 67-77.

Compeau, D. R., \& Higgins, C. A. (1995). Computer Self-Efficacy: Development of a Measure and Initial Test. MIS Quarterly, 9(2), 189-211. http://dx.doi.org/10.2307/249688

Cragg, P. B., \& King, M. (1993). Small-firm computing: motivators and inhibitor. MIS Quarterly, March, 47-60. http://dx.doi.org/10.2307/249509

Davis, D., \& Dunn, P. (2005). You ought to keep good records and use them in management decisions.

Davis, F. D. (1989). Perceived Usefulness, Perceived Ease of Use, and User Acceptance of Information Technology. MIS Quaterky, 13(3), 319-339. http://dx.doi.org/10.2307/249008

Davis, G. B., \& Olson, M. H. (1985). Manaßement Information Systems: ConceptualFoundations, Structure, and Development (2nd ed.). Singapore: McGraw-Hall.

Davis, M. (1997). Transforming Your Firm: Tools for Successful Technology Consulting. The Practical Accountant, Boston, 30(8), S-3.

Delone, W. H. (1988). Determinants of Success for Computer Usage in Small Business. MIS Quarterly, 12(1), 51-61. http://dx.doi.org/10.2307/248803

Dewar, R. D., \& Dutton, J. E. (1986). The Adoption of Radical and Incremental Innovations: an Empirical Analysis. Management Science, 32(11), 1422-1433. http://dx.doi.org/10.1287/mnsc.32.11.1422

Doll, W., \& Torkzadeh, G. (1988). The measurement of end-user computing. MIS Quarterly, 12(2), 259-274. http://dx.doi.org/10.2307/248851

Duschinsky, P., \& Dunn, P. (1998). Competitive advantage from IT, Chartech News. The Institute of Chartered Accountants, April, 7.

Ein-Dor, P., \& Segev E. (1978). Organizational Context and the Success of Management Information Systems. Management Science, 24(10), 1067-1077. http://dx.doi.org/10.1287/mnsc.24.10.1064

Everdingen, Y. V., Hillegersberg, J. V., \& Waarts, E. (2000). ERP Adoption by European Midsize Companies. Communications of the ACM, 43(April), 27-31. http://dx.doi.org/10.1145/332051.332064

Feeney, D. F., \& Wilcocks, L. P. (1998). Core IS Capabilities for Exploiting Information Technology. Sloan Management Review, Spring, 9-21.

Foong, S. Y. (1999). Effect of End-User Personal and Systems Attributes on Computer Based Information 
System Success in Malaysian SMEs. Journal of Small Business Management, July, 81-87.

Frissen, V. (1999). ICT en arbeid in het dagelijks leven (p. 84). Den Haag: Rathenau Instituut.

Gable, G. G., \& Raman, K. S. (1992). Government Initiatives of IT Adoption in Small Businesses: Experiences of the Singapore Small Enterprise Computerization Program. International Information Systems, 1(1), 68-92.

Haron, H. (2001). Small Medium Industries in Malaysia. In Ichirou Shiobara (Ed.), International Auditing Environment. Japan: Zeimukeiri-Kyokai Co. Ltd.

Henry, L. (1997). A Study of the Nature and Security of Accounting Information Systems: The case of Hampton Roads, Virginia. The Mid-Atlantic Journal of Business, 33(3), 171-189.

Hunton, J. E., \& Flowers, L. (1997). Information Technology in Accounting: Assessing the Impact on Accountants and Organizations. In Sutton, S. G. (Ed.), Advances in Accounting Information Systems (pp. 3-34). Jai Press Inc.

Igbaria, M., Guimaraes T., \& Davis G. B. (1995). Testing the Determinants of Microcomputer Usage Via a Structural Equation Model. MIS, 11(4), 87-114.

Josept, C., \& Janggu, T. (2003). A Survey on the Computerized Based Accounting System Used among Mmanufacturing Companies in Kuching, Sarawak. Proceedings of the Conference on Social Science Researhers, Kuala Lumpur.

Kirton, M. J. (1984). Adaptors and innovators-Why New Initiatives Get Blocked. Long Range Planning, 17(2), 137-143. http://dx.doi.org/10.1016/0024-6301(84)90145-6

Klein, K. (2002). Balancing the Books-By the Book. Business Week Online (Feb. 4).

Korsching, P. F., \& Allen, J. C. (2004). Locality based entrepreneurship: a strategy for Community economic volatility. Journal of the Community Development Society, 39(4).

Lal, K. (2006). Adoption of ICTs in SMEs. Retrieved from www.i4donline.net

Lees, J. D. (1987). Successful Development of Small Business Information Systems. Journal of Systems Management, 25(3), 32-39.

Liargovas, P. (1998). The White Paper on Growth, Competitiveness and Employment and Greek SMEs. Small Business Economics, 11(3), 201-214. http://dx.doi.org/10.1023/A:1007923221877

Linda, P. (2004). Keeping the Books (6th ed.). Chicago, IL: Dearborn Trade Publishing.

Longenecker, J., Moore, C., Petty, J., \& Palich L. (2006). Small Business Management: An Entrepreneurial Emphasis (13th ed.). Mason, OH: Thomson/South-Western.

Mathieson, K. (1991). Predictiing User Intentions: Comparing the Technology Acceptance Model with the Theory Planned Behaviour. Information System Research, 2(3), 173-191. http://dx.doi.org/10.1287/isre.2.3.173

Mirani, R., \& Lederer, A. L. (1998). An Instrument for Assessing the Organizational Benefits of IS Projects. Decision Sciences, 29(4), 803-838. http://dx.doi.org/10.1111/j.1540-5915.1998.tb00878.x

Morris, S. S., Wordsworth, W. P., \& Hiatt, S. R. (2006). The Value of Networks in Enterprise Development: Case Studies in Eastern Europe and Southeast Asia. Journal of Developmental Enterprenuership, 11(4), 345-356. http://dx.doi.org/10.1142/S1084946706000489

Muske, G., Woods, M., Swinney, J., \& Khoo, C. (2007). Small Business and the Community: Their Role and Importance within a State's Economy. Journal of Extension, 45(1).

National SME Development Council. (2002). SME Annual Report. Malaysia: Bank Negara.

National SME Development Council. (2005). SME Annual Report. Malaysia: Bank Negara.

Neidleman, L. D. (1979). Computer Usage by Small and Medium Sized European Firms: An Empirical Study. Information \& Management, 2(2), 67-77. http://dx.doi.org/10.1016/0378-7206(79)90008-9

Noor, S., \& Mahamad. (2003). Computer-based accounting system: The Case of Manufacturing-Based SME in Northern Region of Peninsular Malaysia. Journal Technology, 39(E), 19-36.

O'callaghan, R. (2005). Technological Innovation in Organizations and Their Ecosystems. In Dutton, W. H., Kahin, B., O'Callaghan, R., \& Wyckoff A. W. (Eds.), Transforming Enterprise: The Economic and Social 
Implications of Information Technology (pp. 1-12). Cambridge MA: MIT.

Porter, M., \& Millar, V. E. (1985). How information gives you competitive advantage. Harvard Business Review, 63(4), 149-160.

Powell, P., \& Xiao, Z. Z. (1996). The Extent, Mode and Quality of IT Use in Accounting. Journal of Applied Management Studies, 5(2), 143-158.

Raman, K. S., \& Yap, C. S. (1996). From a Resource Rich Country to an Information Rich Society: an Evaluation of Information Technology Policies in Malaysia. Information Technology for Development, 7 , 109-131. http://dx.doi.org/10.1080/02681102.1996.9525277

Raymond, L. (1988). The Impact of Computer Training on the Attitudes and Usage Behaviour of Small Business Managers. Small Business Management, 26(3), 9-13.

Rizzoni, A. (1991). Technological Innovation and Small Firms: a Taxanomy. International Small Business Journal, 9(3), 31-42. http://dx.doi.org/10.1177/026624269100900302

Rogers, E. M. (1983). Diffusion of Innovations (3rd ed.). New York: The Free Press.

Sekaran, U. (2003). Research Methods for Business (4th ed.). USA: John Wiley \& Sons.

Shahrum, H., Sharifah Soa'ad, S. Y., Engku, A. B., Kamran, S., Sabri, A., \& Zurni, O. (1996). IT adoption among the small and medium enterprises in the northern region of peninsular Malaysia. Research Report for IRPA Project, School of Information Technology, Universiti Utara Malaysia, Sintok.

Sheridan, J. C., \& Lyndall, G. S. (2001). SPSS Analysis without Anguish. John Wiley \& Sons Australia, Ltd.

Thatcher, J. B., \& Perrewe, P. L. (2002). An Empirical Examination of Individual Traits as Antecedents to Computer Anxiety and Computer Self-Efficacy. MIS Quarterly, 26(4), 381-397. http://dx.doi.org/10.2307/4132314

Thong, James Y. L. (1999). An integrated model of information systems adoption in small business. Journal of Management Information Systems, 15(4), 187-214.

Treadgold, A. (1990). The Role of Distribution Channel Agents in Promoting Innovative Activity in Small Retail Businesses: A Case Study of IT Adoption. Service Industries Journal, 10(4), 651-663. http://dx.doi.org/10.1080/02642069000000080

UNDP. (2003). Malaysia Small and Medium Enterprises, Building an Enabling Environment. United Nations Development Program, Kuala Lumpur, Malaysia.

UNDP. (2007). Malaysia Small and Medium Enterprises, Building an Enabling Environment. United Nations Development Program, Kuala Lumpur, Malaysia.

Wenzler, R. (1996). Strategic Information Systems in Small Business. Masters Thesis, Department of Information Systems, Victoria University of Technology.

Y. L. (1999). An Integrated Model of Information Systems Adoption in Small Business. Journal of ManagementInformation Systems, 15(4), 187-214.

Yap, C. S., Soh, C. P., \& Raman, K. S. (1992). Information Systems Success Factors in Small Business. OMEGA International Journal of Management Science, $20(5 / 6), \quad$ 597-609. http://dx.doi.org/10.1016/0305-0483(92)90005-R

\section{Appendix A}

\begin{tabular}{|c|c|c|c|}
\hline & Melaka Tengah & Alor Gajah & Jasin \\
\hline 1 & A \& S Forwarding & ABSL ENTERPRISE & Ataly Industries Sdn Bhd \\
\hline 2 & ACE Metal Sdn. Bhd & Agile Matrix Solutions Sdn Bhd & Adon Steel Line Sdn Bhd \\
\hline 3 & Adison Appliances Sdn Bhd & Akhadah Exclusive Touch & Angsana Jingga Enterprise \\
\hline 4 & Airis Technic (M) Sdn. Bhd & Applied Kinetics Industries Sdn Bhd & Anjung Bonda Homestay \\
\hline 5 & $\begin{array}{l}\text { Alpha Xenon Engineering Sdn } \\
\text { Bhd }\end{array}$ & Arena IT Sales And Service & Ansal Ternak Enterprise \\
\hline 6 & Alson Haiwa Sdn Bhd & Besfomec Packaging Sdn Bhd & Anzag Industries \\
\hline
\end{tabular}


7 AMG Infotech Sdn Bhd

8 Aneka Bena M.N. Sdn Bhd

9 Anjung Technology Sdn Bhd

10 Applied Chemie Sdn Bhd

11 Areatwo Enterprise

12 Assess Products Sdn Bhd

13 Atlasinar Sdn. Bhd.

14 Best bites Marketing

15 Bio-Nutritional Laboratory (Malaysia) Sdn.Bhd

16 Blackprint Trading Sdn Bhd

17 Chestronic Sdn Bhd

18 Computer Solution Trio

19 Comtec Computer Centre

20 Connectcounty Sdn Bhd

21 Cool Tech Solution

22 DAI-TEC Manufacturing Sdn Bhd

23 Dataran Alam Enterprise

24 Dayamas Enterpsise DCC Computer Centre Sdn Bhd

Diversified Technology (M) Sdn Bhd

27 Dominant Semiconductors Sdn Bhd

28 E-Control Technology Sdn Bhd

29 E-Generation Computer Sdn Bhd

30 Ebelco Industries Sdn Bhd

31 Elemac Precision Engineering Sdn Bhd

32 Elite Ventures Sdn Bhd

33 Emico Enterprise Sdn. Bhd.

34 Engjaya Industries Sdn Bhd

35 Eurojaya Precision Sdn Bhd

36 Ev Oilfield Supply \& Services Sdn. Bhd.

37 Fandora Recovery Sdn Bhd
Byte Computer Services

Copycent Sdn. Bhd.

Drinna Enterprise

Fetta Marketing (M) Sdn Bhd

Framalinus Multibiz Ventures (M) Sdn. Bhd.

General Paper Products (Melaka) Sdn Bhd

HBK Machinery Service Sdn. Bhd.

HSE Resources Sdn Bhd

Impress Steel Wire Industries Sdn Bhd

Intra Tech Engineering \& Trading Sdn Bhd

Jati Beringin Sdn Bhd

Kaoten Packaging Sdn Bhd

KJ Waja Engineering (M) Sdn Bhd

Leading Steel Engineering

Lipta Plastic Industries Sdn Bhd

Mally Jaya Sdn Bhd

Miracell CCS Sdn. Bhd.

Ogy Technology

Orange Solution

P.Plus Plastic Industries Sdn Bhd

Pannu Elastic Industries Sdn Bhd

Parwood Sdn Bhd

Pelorus Services (M) Sdn Bhd

Pulp Technologies Sdn Bhd

RBT Gemilang Enterprise

Rigidtex Sdn. Bhd.
Berkat Maju Enterprise

Chin Guan Chan Sdn Bhd

Chuan Hoe Leong Trading Company

Dasar Asli Sdn Bhd

Eimei Electronics Sdn Bhd

Empire JR Trading

Farmasi Taufiq Lim

Fikiran Sinar Sdn Bhd

Golden Aroma Sdn Bhd

Good Rubber Works Industries Sdn Bhd

Great Nation Enterprise

Heritage Drinks Industries (M) Sdn Bhd

High Grade Packaging Sdn. Bhd. ITI Jasin Resources Sdn Bhd

JAS Inpack Sdn Bhd

Jasin Khoo Enterprise Sdn. Bhd.

K.K. Best Enterprise

Kesidang Teguh Enterprise

Lembah Perdana Enterprise

Long Bow Mfg Sdn. Bhd.

Maju Steel

Mnlagency

Nasiha Homestay \& Enterprise

Nur Aflah Publishers

Orang Kampung Holdings (M)

Sdn. Bhd.

Orisystems Opto Sdn Bhd

Perniagaan Orang Kampung

Sdn Bhd

Pasrho Trading

Pamastha Marketing

Rubi-Foods (Melaka) Sdn Bhd

Ry Industries Sdn Bhd 


\begin{tabular}{|c|c|c|}
\hline 38 & $\begin{array}{l}\text { First Century Networks } \\
\text { Sdn.Bhd }\end{array}$ & Ss Ipro Marketing \\
\hline 39 & Forecorp Venture Sdn Bhd & $\begin{array}{l}\text { Syarikat Perabot Kiat Huat Sdn } \\
\text { Bhd }\end{array}$ \\
\hline 40 & Genius Lube Enterprise & Tegas Tani Enterprise \\
\hline 41 & Globetech Enterprise & Umbai Resources (M) Sdn Bhd \\
\hline 42 & $\begin{array}{l}\text { GOH Fiberglass Industries } \\
\text { Sdn Bhd }\end{array}$ & Unicocomas Industries Sdn. Bhd. \\
\hline 43 & Golsta Sdn Bhd & Uraz Corporation Sdn Bhd \\
\hline 44 & Guan Seng Steel Sdn Bhd & Usma Brilliant Enterprise \\
\hline 45 & Hanidi Enterprise & Xxelent Services \\
\hline 46 & $\begin{array}{l}\text { Harta Packaging Industries } \\
\text { (Malacca) Sdn Bhd }\end{array}$ & Yeo Aik Hevea Sdn Bhd \\
\hline 47 & Harvest Ever Enterprise & Zentech Trading \\
\hline 48 & $\begin{array}{l}\text { Hazryn Technologies (M) Sdn } \\
\text { Bhd }\end{array}$ & Zmj Enterprise \\
\hline 49 & Hexachase Packaging Sdn Bhd & \\
\hline 50 & Hexatech Sdn Bhd & \\
\hline 51 & $\begin{array}{l}\text { Hydmectron Engineering Sdn } \\
\text { Bhd }\end{array}$ & \\
\hline 52 & I Pac Pallet Sdn. Bhd. & \\
\hline 53 & I.M Three Hi-Tech Sdn Bhd & \\
\hline 54 & ICT Niaga Enterprise & \\
\hline
\end{tabular}

